\title{
VISUAL MEDIA UTILIZATION IN MASTERING ENGLISH VOCABULARY OF HEARING-IMPAIRED STUDENTS
}

\author{
Maulani Anjani Sukirno \\ IAIN Purwokerto \\ Agus Husein As Sabiq \\ IAIN Purwokerto
}

Abstract: Hearing-impaired students are visual learners. That's why the visual media selection will be the most appropriate media assistance for teachers, especially in teaching vocabulary. This research aimed to investigate the use of visual media and teacher challenges in developing English vocabulary for hearing-impaired students. This research used qualitative descriptive approach. The participants of the research were an English teacher and eight hearing-impaired students in the 8th grade of SMPLB N Banjarnegara. The data were obtained through observation, interview, and students' self-reports. The researchers found that the teacher used limited visual media at around the combination of whiteboard, images, picture dictionary, and realia. The teacher used whiteboard to write and draw the material. Images and picture dictionary were used to give an overview and insight to the students and sign language was used as language instruction in the teaching process. Less practice pronouncing the words and misunderstanding on reading the lips movements became the challenges for the teacher. Furthermore, the teacher has less technical skills to utilize technologicalbased media in delivering the materials.

Keywords: Visual Media, Vocabulary, Hearing-impaired Students

\section{A. INTRODUCTION}

Vocabulary is used to developing reading comprehension, listening comprehension, speaking, writing, spelling, and pronunciation. As David Wilkins quoted (1972, cited in Lessard-Clouston, 1994), "without grammar, little can be conveyed, but without vocabulary, nothing can be conveyed". This simply explains that vocabulary is one of the basic elements that must be mastered by people who want to learn English. Lack of vocabulary will place the learners at risk of delayed language skills throughout their life. Learning vocabulary is not just for them who do not have disabilities, but for students who have special needs, they have to learn English as their foreign language too. This is appropriate with the law of government number 20 the year 2003 about National Education System article 32 which contains: "Special Education (Extraordinary Education) is education for students who have an obstacle to follow learning process because physical disorder, mental, emotional, social”. 
Lessard-Clouston (2013) defined vocabulary as “...the words of a language, including single items and phrases or chunks of several words which covey a particular meaning, the way individual words do". In Longman Dictionary, vocabulary is an essential component of language proficiency that provides much of the basis for how well young learners speak, listen, read, and write (Richards, 2011). Vocabulary is more important than grammar, basically. Vocabulary mastery will lead the students to comprehend what the others mean. Also, improving their vocabulary will improve their competence and social confidence. Rivers and Nunan (cited in Alqahtani, 2015) argued that acquired vocabulary is required for a successful second language because without vocabulary we will not be able to use the structures and the functions that we have learned for understandable communication.

As mentioned before, students with special needs are required to be able to mastering vocabulary well, especially students with hearing impairment. IDEA (Individuals with Disabilities Education Act) uses the term of hearing-impairment to describe children who have permanent or fluctuating impairment in hearing but it does not include under the definition of deafness (Bayat, 2012). Hearing impairment can affect the performance of student competencies depending on the severity. Hearing impairment can be diagnosed during the baby's developmental stage or throughout the life of the individual. Likewise, the cause of hearing loss can be caused by developmental damage or cochlear damage from exposure to noise that is too loud (Colclasure, Thoron, \& Larose, 2016).

For hearing-impairment students, they do not only have the disorder in hearing but also they have the disorder in speaking. Speaking ability is influenced by how often they listen to the conversation. This is why their vocabulary is very limited, because they cannot listen what people say so they cannot get new vocabulary. Luckner, Slike, \& Johnson (2012) reported that hearing-impairment students are delayed in vocabulary mastery, having smaller lexicons, slow rates in acquiring new words, and finally they will face difficulty with concept demands of many contents of area discussion.

Teaching English vocabulary for students with hearing-impaired is not as easy as teaching ordinary students. Hearing-impaired students usually have some problems in learning foreign language vocabulary, and it's connected with the difficulties to master their national spoken language (Domagała-Zyśk, 2016). As (Birinci, 2014) stated that teaching vocabulary to deaf and hard of hearing students is not an easy way because of several repetitions they need in order to understand lips movements and use words 
correctly. They can not learn verbal language skills such as listening, speaking, and pronunciation. Thus, teaching vocabulary is more important than reading and writing.

Teaching English will be more effective and easily understood if the teacher uses appropriate media. For students with hearing impairment, the most appropriate learning media to be applied is visual media, because hearing-impairment students learn using visual not audio (Rizki, 2016; Susilo Adi \& Fadhilah, 2017). Visual media itself is a thing or material in the form lines, color, shape, and space designed to deliver the message. The message includes data and information that deliver from source to receiver, both containing of learning content and general information such as newspaper, television, and other media (Yaumi, 2018).

The use of visual media can help learners to remember vocabulary better because the memory for object and pictures are very reliable and also visual media can act as cues for remembering words. Wang et al (2015, cited in Mu et al., 2019) showed that the combination between text and images can improve the result learning, a good image can add the value of content text and give learning satisfaction for students. Combining words and some graphics can be helpful for the students who are deaf or hard hearing to succeed in school (J. Luckner, Bowen, \& Carter, 2001; J. L. Luckner et al., 2012).

Learning styles of deaf students are usually visual and kinesthetic to take care of their inability to hear (Marschark, Lang, \& Albertini, 2002). Therefore, many educators and researchers suggested building visual learning environments by displaying visual materials and aids including pictures, graphics, poster, and films besides using sign language, speech reading, and fingerspelling. Using images during reading aloud can improve vocabulary mastery and boost comprehension for deaf or hard of hearing students. They can build their vocabulary through real objects displayed in colored pictures and printed words (Trussell \& Easterbrooks, 2014). Gallion (2016) concluded that the combination of sign language and pictures will develop deaf or hard of hearing students' cognitive skills, phonemic awareness, and phonics.

Some research has been conducted in investigating visual media for hearingimpairment students. Sa'adah \& Atikah (2019) conducted classroom action research in improving deaf students' vocabulary trough poster media. They said that using Poster media with a carton paper converted into a tree viewer can make the students more interest to learn and easy to understand. Visual scaffolding is also reported as an effective strategy to help the students in memorizing new vocabulary (Hadi, Wahyuni, \& Sulistyawati, 2019). Meanwhile, Birinci (2014) conducted experimental research to investigate the effectiveness of using all kinds of visual materials on teaching vocabulary to hearing- 
impaired students. She concluded that visual materials are more effective than the sign language which does not include any visual materials in teaching vocabulary to deaf learners of EFL.

Based on the background of the study above, the researchers limit the problems that are going to be discussed. This research focuses on the use of visual media in developing the vocabulary mastery of hearing-impaired students in SMPLB $N$ Banjarnegara. The objectives of this research are: (1) to analyze how visual media is used by the teacher in developing vocabularies for hearing-impaired students; and (2) to investigate the challenges on the use of visual media in developing their vocabularies.

\section{B. METHOD}

Based on the variables of the research, the researcher used qualitative method. Qualitative research is defined as research procedures that concern with qualitative phenomenon in the form of written or oral words from people and observable behavior (Bogdan \& Knopp, 2003; Kothari, 2004). The focus of qualitative research is to offer indepth descriptions, interpretations, and clarifications of naturalistic social contexts using multiple data sources (Croker, 2009). The researchers chose this type of research because this research investigated all of the information include facts and will be described in the narration about the use of visual media in developing the vocabulary of hearing-impaired students.

The researchers conducted the data from the principal, the teacher, and the 8th grade which consisted of eight students of SMPLB N Banjarnegara as primary data sources. The secondary sources in this research were the process of the use of visual media in developing vocabularies of hearing-impairments students in SMPLB $N$ Banjarnegara. The researchers also gained the information from all written materials including lesson plan, assessments score sheets, students' works, and learning materials.

Referring to data collection techniques, the researchers used some techniques and instruments. They are (1) observation, the researchers used systematic observation using observation guidelines to observe students activeness and the use of visual media towards hearing-impairment students in developing their vocabularies; (2) interview; the researcher used semi-structured interview in order to get the information the principal about what achievements that have ben ever achieved by the students in English subject and about the facilities in that school. The researchers also did the interview with the teacher to get information about the application of visual media and the influences to students' vocabularies in SMPLB $\mathrm{N}$ Banjarnegara; and

(3) documentation, 
documentation was obtained from observation sheets, interview sheets, students' selfreports, and photographs during the program.

The researchers analyzed data using inductive analysis. The steps were reducing data, presenting data, and conclusion. Then the researchers used triangulation as data validity test. Triangulation involves using multiple data sources in an investigation to produce understanding. The researchers used triangulation data from interview, observation, documentation, and students' self-reports. Wherever the data collected from all sources were similar, the data were considered true and trwutworthly.

\section{FIDINGS}

Based on the type of research method used by researchers in data collection, the researchers did the research in the $8^{\text {th }}$ grade of SMPLB N Banjarnegara, this decision was taken because it was difficult to do the research in the $7^{\text {th }}$ and the $9^{\text {th }}$ grade. At the time of observation, the teacher revealed that the the $7^{\text {th }}$ grade students were still lack in reading, it would be difficult to teach English to them. On the other hand, the $9^{\text {th }}$ grade students only consisted of 3 students.

\section{The Severity Level of Hearing-Impairments}

Based on interview with the principal, the teacher, and school documents, all of the students were included in congenital hearing loss because they have hearing impairments from birth. It can be from heredity factor, developmental damage before birth, or cochlea damage. Their level of severity included sensorineural hearing impairments in which this hearing loss is permanent because it can't be fixed medically or surgically. Therefore, the can use hearing tools to help them hear voices.

\section{English Learning in SMPLB N Banjarnegara}

English language learning at SMPLB N Banjarnegara for $8^{\text {th }}$ grade takes place once a week, on Thursday. The learning process takes place adapted to the available time allocation of 45 minutes $x 2$ hours of study. This learning starts at 11:00 until 12:30. This is because the curriculum for SLB students is $60 \%$ skills and $40 \%$ subject matter or theory.

During the learning process, the researchers became observers as if not seen by the teacher and students. Education standards for students with hearing impairment are almost the same as normal children in general. This is because students with hearing impairments have the same intellectual potential as normal children, only they are constrained by their communication skills. It is just that their standard of achievement is 
a little lower than other students in general. In this case, learning English in students with hearing impairment is more focused on the discussion of the vocabulary of objects around which they often encounter, brief conversations every day.

Based on the result of observation and interview, the steps taken by teacher are helpful for students to understand the new vocabulary that teacher explained. Because students with hearing impairments learn sign language and mother language for their first language. So when the teacher directly teaches them by using English they will find difficulty in understanding it. As mentioned by the teacher, the goal of teaching English for students with hearing impairments is for improve their vocabularies, because their vocabularies are very limited. The teacher said:

"The goal is to add students' vocabulary when he goes out to public places that there are cautions such as welcome, no smoking, parking area, etc. they can understand. The point is to introduce languages or vocabulary outside to the students so they know "oh this is the mean". It's simple we don't overdo it, the important one is students can understand what the meaning of those words or sentences."

\section{Kinds of Visual Media in Learning English in SMPLB N Banjarnegara}

In carrying out English teaching and learning process, the researchers found that the teacher usually uses visual media such as whiteboard, images, picture dictionary, and realia to deliver the material and explanation to the students. Regarding the reason for choosing those kinds of visual media, the teacher said:

"Meanwhile the media I use is still less, most like this (showing images), simple pictures, whiteboard, picture dictionary, and realia. If you use media like computer, I haven't time yet to make the media. If just download I can, but I am unable to operate the facility here. The point is that I have no time yet to put the LCD or to make the media by using computer. So, well for electronic media, I haven't used yet."

The teacher just used the media that already available in the class. The teacher never made media by his-self. Sometimes, the teacher brought a laptop to school but he never used it to teach the students. As mentioned above by teacher, he said that he did not have enough times to make a technological-based media; altough the school took a responsibility in providing the facilities to help teaching and learning process.

Here is the explanation of the kinds of visual media that teacher used based on observations and interview, as follows:

a. Whiteboard is usually used by the teacher to write the material or draw objects.

The teacher used this media to explain about the material to the students by translating simple text in English to Indonesian. The teacher also explained the 
words which students did not know on whiteboard by drawing the objects. For example, students asked about the word "hat", then the teacher drew a hat on whiteboard, no need explanation students could get what the mean of hat. The teacher reported:

"I draw on the whiteboard, for example, a picture of mosque, students have already known "oh that's a mosque," then what I tell the English word".

b. Images were used by the teacher to make easy to understand vocabularies. Based on teacher's practice in the class, the teacher delivered material about name of fruits. The teacher wrote the list of fruits name on whiteboard in English first and then asked the students to search for the meaning in Indonesian. When the teaching and learning process took place there was a student asked "what's the meaning of grape?" The teacher showed the picture of grape, and then the students looked

like "ah, I see". So, images were used to give a figure about things to the students. It helped the students to remember or understand easily.

c. Picture Dictionary is similar with images in use and application. The teacher showed the picture to students to explain what the name was in Indonesian first and then translated it into English. From the teacher's practice, he showed the picture of animals from the picture dictionary. He asked the students to write the name of animals that he had shown on their books and remember the names. Then he asked the students one by one to evaluate about how many names they remember. The teacher showed the images of animals and asked the students to write the answer on whiteboard. When the students could not remember or just remember a little bit, the teacher would pass over them to next students and back to that students when all of his/her friends did it.

Realia was used by in ting the students to study in out door class. The teacher explained the names of objects around them in Indonesian then translated it into English.

\section{DISCUSSION}

\section{Instructional Visual Media for Hearing-impairments Students}

Visual media plays an important role to assist the teachers in delivering the materials. Based on the level of severity, the teacher was led to bring the learning process effectively, easily, and comprehensibly. Through visual media, students with hearing impairments will more easily understand the materials because they can see how the form 
or shape of goods or animals or something else. There are some steps teacher uses while teaching vocabulary for students with hearing impairment. The teacher mostly uses images, picture dictionary, whiteboard, and realia.

For images or picture dictionary, the thing that needed to be prepared is what images that needed in the learning process, that is adapted with the material. For the whiteboard media itself, the teacher only needs to prepare markers to write the explanation if necessary. For realia the teacher can bring some objects that he needed.

As mentioned above, hearing-impaired students are visual learners, the use of images can attract their attention easily because of usually images consist of color and object. By using images media, students find it easier to remember new vocabulary words because they can see the shape of the object being explained. This is very helpful for students to remember the name and shape of the objects. Using images and picture dictionary can ease the hearing-impairments students to catch real ideas and meanings on the objects. It was reported that the students had positive interest to learn English with the non-high standard of achievement. (Sa'adah \& Atikah, 2019) have done classroom action research and found that using poster can improve students' interest and vocabulary mastery.

Picture dictionary is a dictionary consists of the pictures of things or objects. Same as images, this media used by the teacher to gives an explanation and visualization to students. Compared to ordinary dictionary, the use of visual media help the students to know which word that often use by other people. The use of picture dictionary also has effectiveness in developing students' vocabulary (Rizki, 2016). They are easy to know the name of things and the figure because the teacher usually taught the name of things around them first.

In the implementation of realia, the teacher brought the students out of class and showed them objects that the students likely did not know yet. The purpose of using this media was to give students the opportunity to experience vocabulary development in reallife situations. Realia and pictures can not only be used in classroom activities, but parents also can use them to facilitate their children learning at home (Widya, Yuliana, \& Sofiani, 2018). Birinci (2014) also included realia as one of visual media that has positive impact on deaf students vocabulary development. Using realia can bring the students with special needs especially deaf or hard-of-hearing students to meaningful context (Abdallah, 2015).

The teacher used the whiteboard as the main media which is almost used every day. Whiteboard media is used to write new words or draw objects to give visualization to the students so that students can understand what is explained by the teacher. For 
example, the teacher wrote a list of names of fruits, objects, or utterances, etc. on the board. When the teacher taught the vocabulary by writing on whiteboard and then show the images of those things, the students said "Oh this thing's name is this", "The English is this.", "Ah, I see". The use of images as a visualization of the material makes it easier for students to remember. In addition, this media helped the teacher to give more explanation about how to write the vocabulary and how to read it. For example, the word "book", the teacher wrote "Buku = Book = Buk". Although the students could not pronounce the word clearly, but at least they knew how to pronounce it; this media is not always interesting students' attention due to monotonous and less of variations.

Although the teacher limited the selection of instructional visual media; he could utilize the mediaeffectively to support the students in developing their vocabulary mastery. Non-projected visual media still have a big impact to improve students' language skills and academic achievements. Hadi et al. (2019) reported that drilling and visual scaffolding helped the students to memorize new vocabulary and make better understanding. The use of appropriate visual media based on the severity of hearing impairments can facilitate the learning process, strengthen basic knowledge, and explain ideas and concepts (Razalli, Yusuf, Kassim, \& Mamat, 2017).

The teacher reported that he didn't make a high standard in English language learning. The goals were to encourage the students to engage the learning process and introduce them common words or phrases in English when they go to public places. However, the main objectives of teaching English for hearing-impaired students is to introduce language and speech of other nations as well as familiarize them with some elements of culture and civilization in English-speaking countries them (Domagała-Zyśk, 2016).

\section{Basic Considerations on Visual Media Selection}

Teachers should consider the media selection in accordance with the students' characteristics, learning abilities or disabilities, and accessibility. Hearing-impaired students are included in sign-language community in which the auditory ways are not effective. Visual oriented media will alternate them to sequentially pay attention and engage the learning process. Besides, the assistance of visual media can mediate them to acquire new words. Visual media could help the teachers to provide comprehensible input to acquire new vocabulary. Cooper Matthews, (2016) found that the combination of words and images can improve students' learning comprehension. The acquisition, maintenance, and generalization of expressive vocabulary can be increased by demonstrating sign language with the combination of pictures for deaf or hard-of-hearing 
students. Also, error correction can be used to ensure the students produce sign correctly when presented with the picture (Davenport, Alber-Morgan, Clancy, \& Kranak, 2017).

Selecting the most suitable instructional media is very crucial for successful learning. The utilization of visual media may be the most appropriate instructional media for teching hearing-impaired students in accordance with their characteristics as visual learners. Besides that, vocabulary mastery is easily demonstrated using visual-oriented media. As (Persico, 2006) concluded that there are variables influencing media selection. Those are educational purposes, the type of contents, the features of the target population and the constraints imposed by the contexts of production and use.

\section{Teacher Challenges in Vocabulary Learning for Hearing-impairments Students}

The Less of Practice

The less of students' practices are due to unfavorable environments. In a sense in their daily lives, they only meet and interact with people who do not use English to communicate with each other. The lack of practice makes them easy to forget what they have learned before. The more they practice, the more vocabulary they have, as well as the lack of practice, their vocabulary will not develop.

Varying instructional media for developing vocabulary must be assisted with various instructional strategies. The combination of direct and indirect vocabulary development strategies was investigated as meaningful and purposeful strategies to deal with limited vocabulary of hearing-impaired students (Guzin, Umit, Yildiz, \& Zehranur, 2016). On the other hand, the repetition of vocabulary exposures in different contexts could also improve vocabulary development. J. L. Luckner \& Cooke (2010) recommended that teachers can emphasize vocabulary development by providing repeated exposure to new words in multiple contexts, allowing practice sessions in vocabulary instruction, giving enough opportunities to use new vocabulary in various contexts through activities, and integrating explicit vocabulary instruction into other subjects in order to enhance vocabulary acquisition.

\section{Misunderstanding the Means}

Miscommunication was sometimes occurred between the teacher andthe students because of misunderstanding on the lip movements. Some words have similar lip movements with other words. Dealing with hearing-impaired students is likely to have a better understanding of the importance of speechreading. Speechreading and vocabulary are closely related each other. Specchreading ability leads deaf or hard-of-hearing learners to catch accurate phonological representations. Furthermore, Kyle, Campbell, \& MacSweeney (2016) suggested that focus on vocabulary development and speecreading 
skills to deaf learners may form a fruitful basis to help them achieving reading comprehension. Due to lack of speechreading ability, hearing-impaired students have difficulty to guess the right words from the teacher (Ristiani, 2018; Susilo Adi \& Fadhilah, 2017; Yuliani, 2017). That is why the teacher has to write the word on whiteboard or show them images or picture dictionary.

\section{Lack of Technical Skills on ICT Utilization}

The ability in the operation of learning media is absolutely owned by educator (teacher). The lack of teacher's ability, in this case, is the lack of teacher's ability to operate computer-based media or electronic media such as LCDs, Laptops, animation, video, games, etc. As mentioned earlier, the lack of teacher ability in operating advanced visual media affects the delivery of the material, if the teacher is able to convey the material well, then the student will be able to receive the material well also. In addition, the lack of teacher's technical skills on ICT causes the limited media used by teachers. This limitation causes students feeling bored because of the use of the same media every day, paying low attention in learning activities, and eventually affects students' interest in learning (Hadi et al., 2019; Razalli et al., 2017; Ristiani, 2018; Susilo Adi \& Fadhilah, 2017).

Teachers in special education should concern and proactive to develop their teaching methods and media development in order to build a meaningful classroom environment. Thus, the conventional media needs to be enhanced and up to date with the current technology (J. L. Luckner et al., 2012; Razalli et al., 2017). The use of multimedia technology is reported effective to facilitate language acquisition of hearing-impaired students and improve students' academic competence (Winarsih \& Pianora Sarris, 2018; $\mathrm{Xu}, 2018$ ). Mpofu \& Chimhenga (2013) said that assissting new technology and the internet in delivering teaching materials for deaf learners can be used to bridge many gaps.

\section{E. CONCLUSION}

The different levels of hearing-impaired severity will impact to the various instructional media selected to deliver the materials purposefully and meaningfully. Accessibility, availability, and intelligibility would become the basic considerations to the selection of instructional media for hearing-impaired students. The combination of whiteboard, images, picture dictionary, realia, and sign language could improve hearingimpaired students' English vocabulary and make them easier to acquire. However, the teacher should minimilize unmotivating factors to learn and engage in learning activities 
by applying various strategies, providing fun and interesting media, gaming, and more advanced teaching aids.

\section{REFERENCES}

Abdallah, M. M. (2015). TEFL/TESOL for Students with Special Needs: For EFL Student Teachers. In Online Submission. Retrieved from https://files.eric.ed.gov/fulltext/ED557723.pdf

Alqahtani, M. (2015). The importance of vocabulary in language learning and how to be taught. International Journal of Teaching and Education, III(3), 21-34. https://doi.org/10.20472/te.2015.3.3.002

Bayat, M. (2012). Teaching Exceptional Children (Second Edi). New York: Routledge.

Birinci, F. G. (2014). the Effectiveness of Visual Materials in Teaching Vocabulary To Deaf Students of Efl. Hacettepe Üniversitesi Turkey.

Bogdan, R., \& Knopp, S. (2003). Qualitative Research for education. Qualitative Research. https://doi.org/10.1177/1468794107085301

Colclasure, B. C., Thoron, A. C., \& Larose, S. E. (2016). Teaching Students with Disabilities : Hearing Impairments and Deafness. Florida.

Cooper Matthews, S. (2016). Instructional design for deaf students: An experimental study of multimedia instruction and cognitive load (University of Kentucky). https://doi.org/https://doi.org/10.13023/ETD.2016.460

Croker, R. A. (2009). An introduction to qualitative research. In Qualitative Research in Applied Linguistics: A Practical Introduction (2nd ed.). https://doi.org/10.1057/9780230239517

Davenport, C. A., Alber-Morgan, S. R., Clancy, S. M., \& Kranak, M. P. (2017). Effects of a picture racetrack game on the expressive vocabulary of deaf preschoolers. Journal of Deaf Studies and Deaf Education, 22(3), 326-335. https://doi.org/10.1093/deafed/enx015

Domagała-Zyśk, E. (2016). Vocabulary Teaching Strategies in English as a Foreign Language Classes for Deaf and Hard-of-hearing Students. In E. Domagała-Zyśk \& E. H. Kontra (Eds.), English as a Foreign Language for Deaf and Hard of Hearing Persons: Challenges and Strategies (pp. 135-150). Newcastle: Cambridge Scholars Publishing.

Gallion, T. (2016). Improving Vocabulary Comprehension for Deaf or Hard of Hearing Students. M 